\title{
Contributions of Charcoal Production to Socio- Economic Activities of Rural Dwellers in the Rain Forest Agro-Ecological Zone of Nigeria
}

\author{
Eniola $\mathrm{PO}^{1 *}$, Odebode $\mathrm{SO}^{2}$ and Ayandele $\mathrm{B}^{1}$ \\ ${ }^{1}$ Department of Agricultural Technology, the Oke-Ogun Polytechnic, Saki Oyo State, Nigeria \\ ${ }^{2}$ Department of Agricultural Extension and Rural Development, University of Ibadan, Nigeria
}

Submission: June 17, 2018; Published: November 21, 2018

*Corresponding author: Eniola PO, Department of Agricultural Technology, the Oke-Ogun Polytechnic, Saki Oyo State, Nigeria

\begin{abstract}
Charcoal has been found to be a major forest product whose role as a source of rural dwellers' livelihood has not been fully examined. The study investigated the socio-economic contributions of charcoal production to rural dwellers livelihood in the rainforest zone of Nigeria. Data were obtained through the use of structured interview schedule administered to eighty three respondents sourced through snowball. The data were subjected to descriptive statistics, analysis of variance and regression analysis at $\mathrm{p}=0.05$. Most respondents were male (88.0\%), $59.0 \%$ had primary school leaving certificate, married (90.4\%), charcoal production (CP) as secondary occupation (81.9\%) with mean age of $46.0 \pm 9.4$ years, mean for years of experience was $11 \pm 4.3$, with income of $\$ 190,421.9$ per annum from charcoal and $96.4 \%$ made use of earthen mound method with only $36.1 \%$ produced above $128000 \mathrm{Kg}$ of charcoal per annum. Charcoal was mainly produced in the dry season with an average of between 64032 and $96000 \mathrm{~kg}$ per annum. One hundred percent of respondents got high/quick income, more material processions and alternative venture to crop production from CP. Constraints included insufficient labour, funds, transportation, trees and lack of improved production methods. Significant difference existed between level of CP in the dry and rainy seasons $(\mathrm{t}=18.262)$. Significant relationship existed between sex $\left(X^{2}=46.358\right)$, marital status $\left(X^{2}=14.358\right)$, income from CP $(r=34.249)$ and level of CP $(r=54.248)$ had significant influence on the contributions of $\mathrm{CP}$ to the rural dwellers. There is urgent need to create more awareness on the need to replace cut trees and to use improved methods in producing charcoal so as to enhance rural dwellers' income.
\end{abstract}

Keywords: Charcoal production; Quick income; Earthen mound method; Rural dwellers

\section{Introduction}

Agriculture plays a dominant role in the economic development of any country. It dominates major policies in many developing countries such as Nigeria. It is a major source of income for most households, organisations and industries. Despite the dominant and significant role of the petroleum sector in Nigeria, agriculture serves as the bedrock of the economy as it contributes the largest share of the Gross Domestic Product. Agriculture also serves as the largest employer of labour [1]. Though crops, animal products, medicinal herbs, pulp, timbers and firewood as agricultural products contribute immensely to the livelihood of inhabitants of the study area, the contributions of charcoal to their livelihood cannot be ignored.

The importance of charcoal as a source of energy cannot be over emphasized when considering its domestic and industrial use. About 2.4 billion people rely on traditional biomass, mainly for cooking and heating [2].

Charcoal is largely produced and used in rural and urban areas to meet the various energy needs of both the urban and rural poor, by providing a reliable, convenient and accessible source of energy for heating and cooking at all times and at a relatively stable cost in required proportions [3]. In addition to its export value, charcoal trade at the local level provides income opportunities for many people in the rural and urban areas through small scale retail and wholesale businesses [4]. It is an important and simple means of earning an income [5].

Charcoal is the most important commercial fuel derived from wood. Smoke free, capable of controlled use in a small and cheap stove, and also capable of producing greater heat than wood, it is suitable for a wide variety of industrial and domestic uses especially for use in urban environments. In most developing countries, it is the chief form in which wood fuel is used in towns. Charcoal is also easily stored, takes up less space than wood for a given production of heat and does not deteriorate; it is more easily handled in transport and distribution and is less easily ignited so that it is safer to use than wood [6]. Essentially, larger percentages of producers and marketers of charcoal reside in developing countries, and most of them live in rural areas. 
In developing countries, the pressure on natural resources is more acute because nearly $70 \%$ of the populace are subsistencebased and live in the rural communities [7,8]. For instance, Eniola, and Odebode, opined selectivity of trees for charcoal production has reduced to between 11 and 15 species in the guinea savannah zone of Nigeria.

Thus, reliance on natural resources for food and energy implies that people source for their daily needs from their immediate environment [9]. Half of the world's population use biomass fuels for cooking and heating and the world's production of fuel wood increased between 1970 and 1995 from 1362.4 million M3 to 1875.9 million $^{3}$ [10].

\section{Objectives of the Study}

The overall objective of this study is to assess the socioeconomic contributions of charcoal production to rural dwellers livelihood in the rain forest agro-ecological zone of Nigeria The specific objectives are: to identify the socio economic characteristics of respondents; to describe the methods used in charcoal production; to determine the level of charcoal production; to determine the contribution of charcoal production to rural dwellers livelihood; and to assess the constraints faced by charcoal producers in the study area.

\section{Methodology}

The study was carried out in the rain forest agro-ecological zone of Nigeria. The tropical rain is marked with two seasons. The rainy season begins from April to October and the dry season from November to March. Absolute maximum temperature in the

\section{Result and Discussion}

Table 1: Socio-economic characteristics of charcoal producers. coastal areas of the South is $37^{\circ} \mathrm{C}$ while the absolute minimum temperature is $10^{\circ} \mathrm{C}$. The livelihood diversity of the inhabitants includes agriculture, oil and gas industries, mining, tourism and culture, transportation and others. In the agricultural sector, the following crops are predominantly grown; oil palm, rubber, cashew, pineapple, plantain, banana, citrus and mango. In Nigeria, this zone consists of several types of timber for all large constructional and cabinet making timber. The zone contains the most valuable species of vegetation. The zone also has some principal staple food crops such as yam, cocoyam, sweet potato, maize, rice, groundnut, cowpeas and beans as well as a number of fruits. A number of timber trees such as the African mahogany (Khaya ivorensis and K. grandifoliola), the scented sapele wood (Entandrophragma cylindricum) and iroko (Vilicia excelsa) and others are found in this zone. This zone can be found in the following states; Oyo (parts of Oyo state; Ibadan, Ogbomoso, parts of Ogun state, Osun state (Iwo), Ondo state (Akure), Edo state (Benin-city), Calaba, Uyo, Abia state (Umuahia) and others.

The population of this study comprised of all charcoal producers in the study area. Multi-stage sampling technique was used to select respondents from the population of charcoal producers. Major charcoal producing communities were purposively selected in the zone. Fifty percent of rural communities in the zone were selected using simple random sampling technique. Thirty percent of charcoal producers were selected through snow ball from the population of charcoal producers available in each of the selected communities using simple random sampling technique. A total of eighty three (83) charcoal producers were used as respondents for this study.

\begin{tabular}{|c|c|c|c|c|}
\hline Socio-Economic Characteristics & Freq. & \% & Mean & S6 \\
\hline Age (years) & & & & \\
\hline $25-34$ & 7 & 8.4 & & \\
\hline $35-44$ & 29 & 35 & & \\
\hline $45-54$ & 26 & 31.3 & & \\
\hline More than 54 & 21 & 25.3 & & \\
\hline Sex & & & & \\
\hline Male & 73 & 88 & & \\
\hline Female & 10 & 12 & & \\
\hline Educational Attainment & & & & \\
\hline No formal education & 14 & 16.9 & & \\
\hline Koranic school & 7 & 8.4 & & \\
\hline Pry. School certificate & 49 & 59 & & \\
\hline Secondary certificate & 11 & 13.3 & & \\
\hline OND and above & 2 & 2.4 & & \\
\hline Marital Status & & & & \\
\hline Married & 75 & 90.4 & & \\
\hline Single & 5 & 6 & & \\
\hline Widow & 3.6 & & \\
\hline
\end{tabular}




\section{Recent Advances in Petrochemical Science}

\begin{tabular}{|c|c|c|c|c|}
\hline Divorced & 3 & 3.6 & & \\
\hline \multicolumn{5}{|l|}{ Primary Occupation } \\
\hline Crop farming & 45 & 54.2 & & \\
\hline Fishing & 9 & 10.8 & & \\
\hline Charcoal production & 11 & 13.3 & & \\
\hline Trading & 14 & 16.9 & & \\
\hline Civil servant & - & - & & \\
\hline Hunting & 4 & 4.8 & & \\
\hline \multicolumn{5}{|l|}{ Secondary Occupation } \\
\hline Crop farming & 10 & 12 & & \\
\hline Fishing & 1 & 1.2 & & \\
\hline Charcoal production & 68 & 81.9 & & \\
\hline Trading & - & - & & \\
\hline Weaving & - & - & & \\
\hline Hunting & 4 & 4.9 & & \\
\hline Working as hired labour & - & - & & \\
\hline Years of Experience & . & & 11 & 4.3 \\
\hline less than 5years & 9 & 10.8 & & \\
\hline 6-10years & 16 & 19.4 & & \\
\hline 11-15years & 51 & 61.4 & & \\
\hline more than15years & 7 & 8.4 & & \\
\hline Income from Charcoal Production & & & 190421.9 & 99571.4 \\
\hline Less or equal to100.00.0 & - & - & & \\
\hline $101.000-200.000 .0$ & 38 & 45.8 & & \\
\hline $201.000-300.000 .0$ & 40 & 48.1 & & \\
\hline $301.000-400.000 .0$ & 5 & 6.1 & & \\
\hline \multicolumn{5}{|l|}{ Household Size } \\
\hline Less than 6 & 22 & 26.5 & & \\
\hline $6-10$ & 23 & 27.7 & & \\
\hline $11-15$ & 38 & 45.8 & & \\
\hline Total & 83 & 100 & & \\
\hline
\end{tabular}

Table 1 indicates that the modal age range was between 35 and 44 years $(35.0 \%)$ with a mean age of 46 years. This result is in consonance with the study of Stockholm Environment Institute [2] and [11,12]. which reported that charcoal production appears to be dominated by the active age-range of between 35 and 45years. Majority (88.0\%) of respondents were males. This result is in consonance with the study of [13] who indicated that a high number of women in charcoal production were not expected due to the physical nature of the activity. Moreover, $90.4 \%$ of respondents were married. This implies that lot of money is being realised from the sale of charcoal. Also, 59.0\% completed primary education and $16.9 \%$ had no formal education. Kammen et al [10] in contrast to this study revealed that majority of the people involved in charcoal production in sub-Saharan Africa countries are not formally educated, hence they fit into charcoal production. Furthermore, $54.2 \%$ of respondents had farming as their primary occupation. Shacklon et al [13], in a related study, noted that those who have farming as their primary income generating activity have the tendency to be involved in charcoal production activities because they clear lands which provide easy access to wood for charcoal production. More than three quarter (81.9\%) had charcoal production as their secondary occupation. The mean for the years of experience was $11 \pm 4.3$. The modal class of respondents' years of experience was within the range of 11-15 years (61.4\%). The mean of the annual income from charcoal production activities was N 190,421.9 \pm 55819.4 , while $48.1 \%$ of respondents realized between N 201.00 and N 300.00 per annum from charcoal production. Moreover, Kalumiana [9] infers that $70.00 \%$ of the cash income was realised annually in Tanzania in an area suitable for charcoal production while 20 percent of cash was realised in areas with low availability of trees. About $45.8 \%$ had between 11 and15 persons in their household. Majority of respondents $(74.6 \%)$ made use of family members in charcoal production activities. 


\section{Methods Used in Charcoal Production in The Study Area}

Table 2: Distribution of respondents according to methods used in charcoal production in the study area.

\begin{tabular}{|c|c|c|}
\hline Methods Used in Charcoal Production & Freq. & $\mathbf{\%}$ \\
\hline Earth mound & 80 & 96.4 \\
\hline Pit method & 2 & 2.4 \\
\hline Metal kiln & - & - \\
\hline Mud method & 1 & 1.2 \\
\hline Total & 83 & 100.0 \\
\hline
\end{tabular}

Table 2 shows that majority (96.4\%) of respondents made use of earth mound method of charcoal production. The inherent advantages of the earth mound method such as convenience and high yield of charcoal production may be reasons for the continuous use of the method. According to the World Bank (2008), charcoal is mainly produced with earth mound technology in most countries of Africa.

\section{Respondents' Level of Charcoal Production}

Table 3: Distribution of respondents based on the level of charcoal production in the rainforest zones.

\begin{tabular}{|c|c|c|}
\hline Kilogram of Charcoal & Freq. & $\mathbf{\%}$ \\
\hline Total Dry Season Quantity & & \\
\hline $32-32000 \mathrm{~kg}$ & 11 & 13.3 \\
\hline $32032-64000$ & 13 & 15.7 \\
\hline $64032-96000$ & 26 & 31.3 \\
\hline $96032-128000$ & 2 & 2.4 \\
\hline More than 128000 & 31 & 37.3 \\
\hline
\end{tabular}

\begin{tabular}{|c|c|c|}
\hline Total Wet Season Quantity & & \\
\hline $32-32000 \mathrm{~kg}$ & 8 & 9.6 \\
\hline $32032-64000$ & 1 & 1.2 \\
\hline $64032-96000$ & 1 & 1.2 \\
\hline $96032-128000$ & - & - \\
\hline More than 128000 & - & - \\
\hline No production & 73 & 88 \\
\hline 0verall Total Quantity & & \\
\hline $32-32000 \mathrm{~kg}$ & 11 & 13.3 \\
\hline $32032-64000$ & 13 & 15.6 \\
\hline $64032-96000$ & 25 & 30.1 \\
\hline $96032-128000$ & 5 & 4.9 \\
\hline More than 128000 & 30 & 36.1 \\
\hline Total & $\mathbf{8 3}$ & $\mathbf{1 0 0}$ \\
\hline
\end{tabular}

Table 3 reveals that $36.1 \%$ respondents in the rain forest zone produced more than $128000 \mathrm{Kg}$ of charcoal per annum. During the dry season, $37.3 \%$ and $31.8 \%$ of respondents produced more than $128000 \mathrm{~kg}$ and between 64032 and $96000 \mathrm{~kg}$ of charcoal per annum, respectively. However, in the rainy season, $88.0 \%$ of respondents did not produce charcoal at all, while only $9.6 \%$ produced between 32 and $32000 \mathrm{~kg}$ of charcoal per annum. The implication of the result is that high production of charcoal is only attainable in the dry season in the study area. This may be as a result of high rainfall and thick forest of the zone which prevent charcoal producers to involve in production. This result corroborates the findings of Chaposa [3] that output from charcoal production depends on the season, availability of water, types of wood, vegetation and occupation of the producer.

Contributions of Charcoal Production to the Livelihood of Rural Dwellers in the Study Area

Table 4: Distribution of respondents based on contributions of charcoal production rural dwellers livelihood in the study area.

\begin{tabular}{|c|c|c|c|c|}
\hline Contribution of Charcoal & Yes & & No & \\
\hline & Freq. & $\%$ & Freq. & $\%$ \\
\hline Charcoal production increases my income & 83 & 100 & - & - \\
\hline It increases the chances of getting more material possession. & 83 & 100 & - & - \\
\hline Charcoal production is an alternative venture to crop production & 83 & 100 & - & - \\
\hline It enables me to meet my family's social responsibilities e.g. payment of school fees etc. & 82 & 98.8 & 1 & 1.2 \\
\hline One can never run at a loss by producing charcoal & 7 & 8.4 & 76 & 91.6 \\
\hline It is a source of gainful employment & 83 & 100 & - & - \\
\hline Storing charcoal for sale off season commands a high price & 83 & 100 & - & - \\
\hline It enhances household energy security & 83 & 100 & - & - \\
\hline Monetary returns from charcoal is higher compared to other agricultural activities & 82 & 98.8 & 1 & 1.2 \\
\hline It serves as security against crop failure. & 83 & 100 & - & - \\
\hline Cost of purchasing inputs is cheap compared to farming & 82 & 98.8 & 1 & 1.2 \\
\hline No special skill is required for charcoal production & 82 & 98.8 & 1 & 1.2 \\
\hline Charcoal production is good as an off season business & 81 & 97.6 & 2 & 2.4 \\
\hline Total & 83 & 100 & 83 & 100 \\
\hline
\end{tabular}

Table 4 reveals that charcoal production contributed the following to their livelihood; $100.0 \%$ of respondents got high/ quick income, more material possessions, charcoal production as an alternative venture to crop production, source of gainful 
employment, storing of charcoal for sale off season commands a high price, enhancement of household energy security as well as security against crop failures. Furthermore, 98.8\% said that charcoal production enabled them to meet their family and social responsibilities, that monetary returns from charcoal are higher when compared to other agricultural activities and that the cost of purchasing inputs was cheaper compared to farming. Level of Contributions of Charcoal Production to the Rural Dwellers' Livelihood

Table 5: Level of contribution of charcoal production to rural dwellers' livelihood.

\begin{tabular}{|c|c|c|c|c|c|}
\hline Level of Contributions of Charcoal to Rural Dwellers Livelihood & Scores & Freq. & \% & Mean & SD \\
\hline Low & $\leq 11$ & 2 & 2.4 & 11 & 0.3 \\
\hline High & $\geq 11$ & 81 & 97.6 & & \\
\hline
\end{tabular}

Table 5 shows that majority of respondents $(97.6 \%)$ received greater contributions from charcoal production. The implication of this is that greater contributions derived from charcoal production encouraged respondents to continue with charcoal

production in the study area. CHAPOSA [3] and Wunder [15], also infer that charcoal production attracts high income and is a source of subsidy for crop production.

Respondents' Constraints on Charcoal Production in the Study Area

Table 6: Distribution of respondents based on constraints to charcoal production.

\begin{tabular}{|c|c|c|c|c|c|c|}
\hline \multirow[t]{2}{*}{ Constraints to Charcoal Production N=327 } & \multicolumn{2}{|c|}{ Not A Constraint } & \multicolumn{2}{|c|}{ Mild Constraint } & \multicolumn{2}{|c|}{ Major Constraint } \\
\hline & $\mathbf{F}$ & $\%$ & $\mathbf{F}$ & $\%$ & $\mathbf{F}$ & $\%$ \\
\hline Insufficient labour & 28 & 33.7 & 16 & 19.3 & 39 & 47.3 \\
\hline Insufficient funds & 13 & 15 & 16 & 19.3 & 54 & 65.1 \\
\hline Transportation problem & 31 & 37.3 & 5 & 6.3 & 47 & 56.6 \\
\hline Lack of market for sale of charcoal & 80 & 97.4 & - & - & 3 & 3.6 \\
\hline Lack of sufficient trees & 27 & 32.5 & 13 & 15.7 & 43 & 51.8 \\
\hline Lack of technical know-how & 41 & 49.4 & 27 & 32.5 & 15 & 18.1 \\
\hline Lack of improved production methods & 38 & 11.6 & 82 & 98.8 & 46 & 14.1 \\
\hline Lack of personal tree plantation & 3 & 3.6 & 4 & 4.8 & 76 & 91.6 \\
\hline Insufficient demand for charcoal & 76 & 91.6 & 1 & 1.2 & 6 & 7.2 \\
\hline Little price attraction of charcoal & 57 & 68.7 & 20 & 24.1 & 6 & 7.2 \\
\hline High tax payment on charcoal & 13 & 15.7 & 4 & 4.8 & 66 & 79.5 \\
\hline High chains in supply is required & 78 & 94 & 2 & 2.4 & 3 & 3.6 \\
\hline
\end{tabular}

Table 6 shows that $65.1 \%, 56.6 \%$ and $47.0 \%$ of respondents observed that insufficient funds, transportation problems and insufficient labour were the major constraints. Almost 100.0\% of respondents lacked awareness about improved production

methods and personal tree plantations. However, 78.6\%, 79.5\% and $51.8 \%$ of respondents had insufficient number of trees, had high tax payment as major constraints to charcoal production respectively.

Difference Between Level of Charcoal Production in the Dry and Rainy Season

Table 7: Significant difference between level of charcoal production in the dry and rainy season.

\begin{tabular}{|c|c|c|c|c|c|c|c|c|}
\hline Season N & Df & Mean & Std. Dev. & Std. Error Mean & Mean Difference & T-Value & Sig. & \\
\hline Dry & 83 & 82 & 2786.747 & 1390.23871 & 152.59852 & 2786.74699 & 18.262 & 0 \\
\hline Wet & 9 & 8 & 697.7778 & 747.15758 & 249.05253 & & & \\
\hline
\end{tabular}

Table 7 reveals that there was a significant difference between the level of charcoal production in the dry and rainy seasons in the study area $(t=18.262)$. This implies that quantity of charcoal produced depends on the season. Factors such as easy access to the forest, availability of woods and primary occupation of the people may influence the quantity of charcoal production.

Significant Relationship between Socio-Economic Characteristics and Contribution of Charcoal Production to the Rural Dwellers in the Study Area

Table 8 reveals that age $(r=0.161)$, years of experience $(r=0.219)$, income from charcoal production $(r=34.249)$, level of charcoal production $(\mathrm{r}=54.248)$, household size $(\mathrm{r}=1.488)$, 
sex $\left(X^{2}=46.358\right)$ and marital status $\left(X^{2}=14.358\right)$ had effects on the contribution of charcoal to the livelihood of rural dwellers. This implies that the greater the income accrued from charcoal

Table 8: Significant relationship between socio-economic characteristics and contribution of charcoal production to the rural dwellers in the study area.

\begin{tabular}{|c|c|c|c|c|c|c|}
\hline Variables & Statistical Tool & \multicolumn{2}{|c|}{ R-Value } & \multicolumn{2}{|r|}{ P-Value } & Decision \\
\hline Age & PPMC & & 0.161 & 0.004 & & S \\
\hline Years of experience & PPMC & & 0.219 & 0.05 & & S \\
\hline Income from charcoal production & PPMC & & 34.249 & 0.012 & & $\mathrm{~S}$ \\
\hline Household size & PPMC & & 1.488 & 0.675 & & NS \\
\hline \multirow[t]{2}{*}{ Level of charcoal production } & PPMC & & 54.248 & 0 & & $\mathrm{~S}$ \\
\hline & & Df & $\mathrm{X} 2$ value & P value & Contingency Coefficient (CC) & \\
\hline Sex & Chi-square & 1 & 46.358 & 0 & 0.352 & S \\
\hline Marital status & Chi-square & 3 & 14.358 & 0.002 & 0.205 & $\mathrm{~S}$ \\
\hline Level of education & Chi-square & 4 & 3.931 & 0.415 & 0.109 & NS \\
\hline Primary occupation & Chi-square & 2 & 2.412 & 0.299 & 0.86 & NS \\
\hline Secondary occupation & Chi-square & 5 & 3.9 & 0.564 & 0.109 & NS \\
\hline Membership registration & Chi-square & 1 & 1.306 & 0.287 & 0.018 & NS \\
\hline
\end{tabular}

\section{Conclusion}

Most charcoal producers were males in there active age, married with formal education, having farming as their primary occupation with a high number of years of experience and household size. They made use of the earth mound method of charcoal production which gave them a high quantity of charcoal production in the dry season. Majority of respondents received greater contributions from charcoal production. Respondents observed insufficient funds, transportation problems and insufficient labour, lacked awareness about improved production methods, insufficient trees, high tax payment and personal tree plantations as major constraints. However, marital status, sex, method of charcoal production, output and income from charcoal production as well as constraints to charcoal production had effects on the contributions of charcoal to the livelihood of rural dwellers. Based on this study, the following recommendations were made; there should be specific agro ecological zones that should be allowed for charcoal production. There should be methods to produce charcoal. More foresters/environmental extension agents should be employed and equipped to monitor the activities of rural dwellers in the forest.

\section{References}

1. Amous S (2000) Review of wood energy reports from ACP African countries. EC-FAO Partnership Programme working document, p. 22.

2. Bada SO, Popoola L, Adebisi LA, Ogunsanwo OY, Ajewole OI, et. al. (2009) Impact of biodiversity in selected communities of West Africa. Report submitted to the African Forest Research Network (AFORNET), Kenya, P. 25. ERBIC18CT980278 University Eduardo Mondlane Mozambique Individual partner report 70: 32 . more awareness on the need to use more environmental friendly

3. Chaposa (2002) Charcoal production in South Africa. INCO-DEV production, the more it contributes to the rural dwellers' livelihood $[16,17]$.
4. Cirad (1999) Programme pilote intégré d'approvisionnement durable en bois énergie de la région de Mahajanga. Project report, Mahajanga Integrated Pilot Program (PPIM), Nigeria.

5. Eniola PO, Odebode SO (2018) Rural dwellers' perception of effect of charcoal production on the environment in Guinea savannah zone of Nigeria. Journal of scientific research \&reports 19(1): 1-12.

6. Eniola PO, Odebode SO, Ogunsanwo OY, Ajewole OI (2012) Species Selectivity for Charcoal Production in Three Ecological Zones of Nigeria. Journal of tropical forest resources 28 (1): 17-28.

7. Falcao MP (2007) Personal communication in June 2007, Maputo, Mozambique.

8. http://www.worldenergyoutlook.org/weo/pubs/weo2002/ energypoverty.pdf

9. Kalumiana OS (2000) Charcoal consumption and transportationcovering the March/April 1999 urban household energy consumption survey and the September 1999 charcoal traffic survey, both in Lusaka.

10. Kammen DM, Lew DJ (2005) Review of technologies for the production and use of charcoal. University of California, USA, 3393: 1-26.

11. Malimbwi RE, Zahabu E, Monela GC, Misana SB, Jambiya GLK, et al (2001) Tree species preference, volume estimation and charcoal kiln efficiencies in Eastern Tanzania miombo woodlands. P. 10.

12. SEI (2002) Stockholm Environment Institute: Charcoal potential in Southern Africa, CHAPOSA. Final Report. INCODEV p. 68.

13. Shackleton CM, Shackleton SE, Buiten E, Bird N (2006) The importance of dry woodlands and Rain forests in rural livelihoods and poverty alleviation in Southern Africa. Rain forest Politics and Economics 9: 558-577.

14. WEC (2004) Survey of world energy resources.

15. World Bank (2000) ESMAP Household Energy Strategy. Leaflet.

16. World Bank (2002) A revised forest strategy for the World Bank group.

17. World Bank (2004) Harvesting opportunities. Rural development in the $21^{\text {st }}$ Century. IV Regional Thematic Forum. Printed from the World Bank Group. Latin America and The Caribbean, USA, p. 248. 


(C)
Commons Attribution 4.0 License
Col: 10.19080 RAPSCI.2018.06.555683

Your next submission with Juniper Publishers will reach you the below assets

- Quality Editorial service

- Swift Peer Review

- Reprints availability

- E-prints Service

- Manuscript Podcast for convenient understanding

- Global attainment for your research

- Manuscript accessibility in different formats

( Pdf, E-pub, Full Text, Audio)

- Unceasing customer service

Track the below URL for one-step submission https://juniperpublishers.com/online-submission.php 